\title{
Water Governance in Bangladesh: An Evaluation of Institutional and Political Context
}

\author{
Ngai Weng Chan ${ }^{1}$, Ranjan Roy ${ }^{1,2, *}$ and Brian C. Chaffin ${ }^{3}$ \\ 1 Geography Section, School of Humanities, Universiti Sains Malaysia, Penang 11800, Malaysia; \\ nwchan@usm.my \\ 2 Department of Agricultural Extension \& Information System, Sher-e-Bangla Agricultural University, \\ Dhaka-1207, Bangladesh \\ 3 College of Forestry and Conservation, University of Montana, 32 Campus Drive, Missoula, MT 59812, USA; \\ brian.chaffin@umontana.edu \\ * Correspondence: ranjansau@yahoo.com or ranjan@sau.edu.bd; Tel.: +880-17-1618-6047 \\ Academic Editors: Giacomo Zanni, Davide Viaggi and Meri Raggi \\ Received: 8 August 2016; Accepted: 9 September 2016; Published: 15 September 2016
}

\begin{abstract}
Water crises are often crises of governance. To address interrelated issues of securing access to sustainable sources of safe water for the world's populations, scholar and practitioners have suggested fostering improved modes of water governance that support the implementation of integrated water resource management (IWRM). Recently, implementation of an IWRM approach was announced as a target for achieving Goal 6 of the Sustainable Development Goals (SDGs). This study employs an analytical hierarchy process with a SWOT analysis to assess the current institutional and political context of water governance in Bangladesh and evaluate IWRM as a means to achieve the SDGs.
\end{abstract}

Keywords: water governance; IWRM; SWOT-AHP; sustainable development goals; Bangladesh

\section{Introduction}

Water is the lifeblood of the planet and water resources are inextricably linked to global climate change dynamics [1,2]. The uncertainties accompanying climate change include a potential redistribution of water resources across the globe [3]. This creates a critical problem for water resources management organizations and institutions that rely on socio-political scales to derive authority and legitimacy, and only have the capacity to affect change at these scales. In an effort to provide more workable solutions to these crises of scale mismatch and uncertainty in water resources management, scholars and practitioners have turned to the more inclusive concepts of water governance [4-6]. Governance-as opposed to management $[7,8]$ —is defined as "the means through which political actors choose goals and make decisions and the means through which they take action to achieve those goals" [7]. Governance encompasses more than just government; it includes formal and informal institutions (laws, policies, regulations, and social norms) including markets, as well as organizations and groups of actors that create a direction for the use and allocation of resources (e.g., water) through political processes. Management is often considered the operationalization of governance processes and supporting transparent decision making and is manifest in direct actions on the ground $[8,9]$. The World Water Assessment Programme has stressed that a key need for twenty-first century governance and management generally, is to place water at the heart of environmental decision-making at all levels, e.g., local, regional and global [3].

However, the failure of comprehensive approaches to water governance to take hold and address key water issues in many developing nations is evident worldwide. Since 1990, although " 2.6 billion people have gained access to improved drinking water sources", 663 million people still lack this 
access completely. At the same time, 2.4 billion people lack access to sanitation service, and 1.8 billion people rely on at least one fecal-contaminated drinking water source [10]. In response, the Sustainable Development Goals (SDGs) have identified a series of targets under Goal 6-to "Ensure availability and sustainable management of water and sanitation for all" [10]. These targets are a renewed approach to processes initiated by the Millennium Development Goals (MDGs) [3], but the new targets explicitly include elements of water governance in addition to numerical objectives for achieving access to clean water and sanitation. One such target is to implement integrated water resources management (IWRM) as a means to coordinate across disparate levels and scales of existing water governance. IWRM is defined by the Global Water Partnership as "a process which promotes the coordinated development and management of water, land and related resources in order to maximize economic and social welfare in an equitable manner without compromising the sustainability of vital ecosystems and the environment" [11]. Other aspects of IWRM include integrated groundwater-surface water management, the river basin as focal scale of governance, multi-stakeholder approaches, achieving equity in resource access, and planning for demand management [12].

The addition of IWRM as a target in the SDGs represents a global shift towards a more systematic approach to water resource challenges, an approach that addresses barriers and opportunities at the broader scale of governance as well as at the scale of management implementation. While aspects of IWRM and water governance can be contradictory (i.e., IWRM's focus on centralized basin organizations versus the need to build capacity for emergent informal organizations at the scale of governance), it can also be argued that certain elements of governance are required to operationalize IWRM [13]. Since, IWRM is a process of promoting the coordinated development and management of water, land, and related resources; and water governance refers to the political, social, economic and administrative systems in place that influence water's use and management. For example, IWRM approaches are more likely to claim legitimacy and wield authority if careful attention is paid to building capacity in governance for IWRM by establishing inclusive processes for stakeholders to engage with existing institutions, political processes, government agencies, and other important actors and organizations such as non-government organizations (NGOs).

In Bangladesh, key challenges for water governance include (i) a growing, country-wide demand for water and increased pressure on ground water sources [14]; (ii) negative impacts of climate change including droughts, floods and other natural disasters drastically alter the availability of safe water and water for crop production [15]; and (iii) an alarming rise in pollution due to unplanned industrial growth and poor sanitation conditions [16]. IWRM has the potential to address water and sanitation challenges in developing countries like Bangladesh, a country where water resource management is predominantly the sole responsibility of a few entities-the Bangladesh Water Development Board. This Development Board has weak or non-existent relationships with other governmental ministries (e.g., agriculture and environment) and with local water consumers, particularly with regard to project planning and implementation, infrastructure development, and policy making. As a result, water resource management in Bangladesh suffers from mismanagement, consistent crisis, and increased vulnerability to natural disasters and upstream diversion that inhibits any ability to meet the water demand for a rapidly growing population, as well as the subsequent expansion of agriculture and industry. Several studies [17-19] indicate that this fragmented approach is no longer viable and a more holistic approach-increased attention to enabling aspects of water governance and IWRM implementation-is essential to guide and regulate the use, conservation, and protection of Bangladesh's limited supply of usable freshwater resources.

The effects of climate change may severely increase the vulnerability of Bangladesh's water resources, with the potential to affect the roughly 160 million residents of the country both directly and indirectly through decreased agricultural production [20]. Agriculture is the main consumer of water in Bangladesh followed by the urban residential and industrial sectors [21]. Irrigated areas in Bangladesh are projected to increase by 53\% in 2020 [16], which will further stress groundwater resources and potentially increase the spread and severity of arsenic contamination. Ground water 
arsenic contamination has come out as a serious natural calamity in Bangladesh. Around 35 million people are arsenic affected in both rural and urban areas, and arsenic related diseases have been identified in 37 districts (out of 64) by the National Institute of Preventive and Social Medicine [16]. In addition, Bangladesh's surface water sources and subsequent water governance regimes are subject to the unilateral interventions (e.g., dam building and hydropower development) of upper-basin riparian hegemons (Bangladesh is crossed by 57 trans-boundary rivers, but only $7 \%$ of the total catchment of these rivers lies inside of the country. About $92 \%$ of the country's surface water is provided by out-of-country sources, which is controlled by countries such as India.) including India and China, but also Bhutan and Nepal to some degree [22,23].

Flood is common in Bangladesh and will likely increase under climate change scenarios; drought also poses a major problem for agricultural production in the north western part of the country. On average, $22 \%$ of the country is flooded each year, with predicted increases in the future [16]. Flooding is caused mainly by heavy rainfall during the monsoon season (June-October), which coincides with peak river flows as snow melts into runoff from the Himalayan Mountains. Flood levels are further aggravated by the factors upstream such as land degradation and erosion, development in the upstream basin and confinement of rivers by dikes [23]. The diversion and damming of upstream rivers is also one of major factors responsible for droughts that impact farm production in the north western portion of the country [24,25].

Recently, the Global Water Partnership South Asia conducted a consultation of water stakeholders in Bangladesh [26]. They identified key priorities for increasing effectiveness of water governance across the country by mapping current weaknesses in water management (e.g., "extremely inadequate" waste water management systems). A number of studies [18,24,27-30] also point out the shortcomings of water governance in Bangladesh, including (i) a lack of integration of major water users in planning and implementation; (ii) a communication gap between policy makers and stakeholders; (iii) a shortage of political will for creating an enabling environment for effective water governance; and (iv) marginalization of citizens and a lack of ability to participate in water projects.

This study is designed to further build an understanding of water governance (particularly institutional and political contexts) in Bangladesh and to draw policy insights for implementing an IWRM approach to achieve the SDGs for water [10]. To achieve this, we use a hybrid method-a combination analytical hierarchy process (AHP) and a strengths, weaknesses, opportunities, and threats (SWOT) analysis - to evaluate the compatibility of current water governance in Bangladesh with principles of IWRM. In addition, we briefly assess environmental and climate policy integration in three key Bangladeshi water policy documents: the National Water Policy [31]; the Development Strategy of the National Water Management Plan [32]; and the National Water Management Plan itself [21]. We conclude with a series of policy insights relevant to fostering IWRM in Bangladesh.

\section{Unpacking Water Governance}

Shifting focus to address aspects of water governance as opposed to only discrete management actions has been recognized as a method of promoting sustainable development and responding to local and global water crises [5,6]. Efforts to improve water governance have been significant globally but clearly remain an ongoing process for many least developed countries, particularly for Bangladesh [30]. Although international organizations such as the Organization for Economic Co-operation and Development and the World Health Organization define water governance based on their organizational priorities, mandates and biases, the ultimate goals of fostering more integrated regimes of water governance are generally: to improve people's livelihood opportunities; to determine mechanisms for water allocation and distribution; and to mediate access and control over water resources and associated benefits [9]. The United Nations Development Program's definition of water governance is useful to contextualize our use of the term in this paper: "the political, economic and social processes and institutions by which governments, civil society, and the private sector make decisions about how best to use, develop and manage water resources" [33]. 
The term water governance has been used more recently to refer to emergent and more consensus-driven modes of decision making that are less pre-defined, less subject to strict government oversight and presumably more reflexive, thus enhancing actors' capacity to adapt to complexities and uncertainties of global change [34]. This is in contrast to an "old" notion of governance, which was broadly a synonym for government management of water and the exercise of a command-and-control mode of management with little stakeholder engagement-a mode consistently recognized as less suitable for successfully dealing many of the world's current and complex water management challenges [30]. Water governance instead focuses attention on "process-oriented societal co-steering through formal and informal networks, partnerships and dialogue" [35]. Accountability, transparency and decentralized decision making are generally agreed upon cornerstones of water governance [36]. Additionally, leveraging private financing and empowering women as important water management decision makers are critical to the good governance aspects of any modern water governance framework [37]. In this way, we view water governance less as a rigid or prescriptive system, but more as evolving processes: processes by which decisions over and affecting water management are made and implemented in order to make water accessible to all; processes for embracing multiple actors, organizations and institutions and enhancing partnerships that are relevant to these decisions; and the processes by which citizens exercise their legal rights and obligations to articulate their interests and needs related to water.

\section{IWRM and the Sustainable Development Goals}

The pervasive pollution, exploitation and over-allocation of water in some developing countries combined with inextricable links between water, agriculture, energy and public health, have consistently elevated the narrative of governing water resources to a level of crisis. In response, and in a global effort to eradicate world hunger and poverty, world leaders adopted the MDGs in 2000. Related to water, the MDGs contained the goal of "ensuring environmental sustainability" which included a specific target to halve by 2015 the world population without access to safe drinking water and basic sanitation. Substantial progress has been made toward achieving the MDGs, but as of 2015 many of the targets, including water related targets, have not been fully achieved (e.g., globally one in ten people lack access to safe water) [38]. Thus, the UN recently presented SDGs as a unifying global vision to continue the progress made under the MDGs. The SDGs employ a broad articulation three unifying principles common to the MDGs—human rights, equality and sustainability—but also includes four broad dimensions of implementation: inclusive social development; inclusive economic development; environmental sustainability; and peace and security [39]. Specific to water, Goal 6 (to ensure availability and sustainable management of water and sanitation for all) calls for (i) universal access to safe drinking water, sanitation and hygiene; (ii) the sustainable use and development of water resources; (iii) robust and effective water governance; (iv) improved water quality and wastewater management; and (v) protection and restoration of water related-ecosystems [10].

Unique to the SDGs is a call for the implementation of IWRM across multiple scales of water governance-local, regional and beyond. This inclusion of IWRM represents a formal recognition that achievement of the SDGs cannot be realized without an integrated approach to water policy and implementation of that policy that includes existing governments, agencies, stakeholders, and institutions [40]. An IWRM approach emphasizes (i) multiple objectives for water at different social-ecological scales; (ii) coordination across governments, agencies and organizations; and (iii) inclusive and open decision-making processes for stakeholders, including those lacking in capacity to participate [41]. However, IWRM does not just "work" in all contexts, certain aspects of governance ripe for fostering an IWRM approach must be present. In many developing nations, the "true integration" required of both policy $[13,19]$ and science (e.g., shared data systems, consensus-based or co-produced analysis of data) for IWRM to be successful faces significant social, political, economic, and technological barriers [40]. Bangladesh is no exception. In the remainder of this paper, we analyze key water institutions, organizations, and policy documents in Bangladesh 
to create a contemporary picture of water governance in the country. Through both a literature review (Peer-reviewed literature: [13-19,22-25,27-29,42-44] and grey literature: $[21,26,32,45,46])$ and empirical analysis, we highlight the potential for IWRM to take root under the current structure of water governance in Bangladesh.

\section{Institutional and Political Contexts of Water Governance in Bangladesh}

Governance in Bangladesh generally has a poignant history of contestation [47] including the relatively recent (1971) struggle for independence and several military coups since. Similarly, water governance in Bangladesh is in a state of punctuated development and consistent change [28]. In this section, we attempt to identify, understand, and evaluate the roles of various institutions (e.g., policies, mandates, actions plans and strategies), processes of policy making, and stakeholder groups and organizations that may impact the capacity to build IWRM in Bangladesh. Below, we categorize this assessment by reviewing the following aspects of water governance in Bangladesh: roles of institutions and organizations; planning processes; existing policies and politics; and decision making processes.

\subsection{Institutions and Organisations}

The development of institutions and organizations affecting water governance in Bangladesh can be traced to the 1950s. At that time, the East Pakistan Water and Power Development Board Authority was formed and given authority to manage water in East Pakistan, what was to eventually become Bangladesh. After the independence in 1971, the Board was abolished and the Bangladesh Water Development Board was created in 1972, which became the principal agency for managing water resources and controlling flood, drainage and irrigation projects. After 1972, a number of government agencies, NGOs and other private organizations either emerged or engaged in water development projects in Bangladesh (see Table 1). Despite the plethora of aid organizations and other NGOs working on water projects in Bangladesh today, these initiatives are often fragmented and lack coordination between each other and the official Bangladeshi ministries concerned with water [42]. Some reasons for this lack of coordination include: information and data sharing is not embraced by the government; no guidelines or action plans exist for integrating water development projects with the major water consumers; and the harmonization and alignment of foreign aids from development partners and donor organizations is extremely difficult and thus uncommon.

\subsection{Planning Processes}

A number of key government policies (governing documents) were reviewed to understand the planning processes related to water governance in Bangladesh. We report on three planning processes here that have potential links to enhancing water governance and creating space for IWRM in Bangladesh. In addition to envisaging poverty alleviation and minimizing inequity, the 2nd Poverty Reduction Strategy Paper (2012) places emphasis on "water resources development and management" and identifies challenges including the unchecked overexploitation of groundwater. This Paper outlines a broad set of strategies to deal with water related crises, including disaster risks management [48]. This policy direction emphasizes a multi-stakeholder approach toward participation in water project planning and implementation, but lacks an overarching plan for IWRM [11]. Specifically, this Paper does not address: gender equality as a means to strengthen water governance; measures to address poverty alleviation as a component of water access; and the roles of the private sector in water management. Development targets in the Poverty Reduction Strategy Paper are neither specific nor based on a time scale that promotes adequate planning processes, which is one of the major development problems in Bangladesh generally [48]. Although the Paper calls for increased stakeholder participation in water planning processes, the policy does not address important water governance elements (e.g., ignores institutional accountability), and thus alone does not create adequate space for the development of IWRM in Bangladesh. 
Table 1. Four eras of evolution of water policies in Bangladesh, Source: $[17,27,28,42]$.

\begin{tabular}{|c|c|c|c|c|}
\hline Era & $\begin{array}{l}\text { Laying the Foundation of Water } \\
\text { Institution (1947-1988) }\end{array}$ & $\begin{array}{l}\text { Establishing the Flood Action Plan } \\
\text { (1989-1994) }\end{array}$ & Restructuring the Water Sector (1995-1998) & Evolution of Water Governance (1999 to Date) \\
\hline Main Concerns/Goals & $\begin{array}{l}\text { Establishment of key institutions } \\
\text { (e.g., BWDB) of water management }\end{array}$ & $\begin{array}{l}\text { Strategy formulation for controlling and } \\
\text { managing floods }\end{array}$ & $\begin{array}{l}\text { Overhaul the water management systems, } \\
\text { particularly, decision making process }\end{array}$ & $\begin{array}{l}\text { Developing calibrated policy instruments to face } \\
\text { water challenges }\end{array}$ \\
\hline Main Issues & Increasing agricultural production & $\begin{array}{l}\text { Controlling floods, particularly saving } \\
\text { crop cultivation }\end{array}$ & $\begin{array}{l}\text { Integrated planning and management and } \\
\text { preserving water resources }\end{array}$ & $\begin{array}{l}\text { Managing water demand and crisis by } \\
\text { leveraging science and technology }\end{array}$ \\
\hline Main Instruments & A 20-years Water Master Plan (WMP) & The Flood Action Plan (FAP) & $\begin{array}{l}\text { The Guidelines for People's Participation } \\
\text { (GPP) for water development projects }\end{array}$ & $\begin{array}{l}\text { The National Water Policy and National Water } \\
\text { Management Plan (NWMP) }\end{array}$ \\
\hline Key Features & $\begin{array}{l}\text { Preparing WMP was the initial step of } \\
\text { water planning. It overemphasized surface } \\
\text { water interventions and overlooked } \\
\text { ground water management. In this era, } \\
\text { water management was followed mainly } \\
\text { "sectoral approaches" and "structural } \\
\text { engineering solutions" that raised much } \\
\text { criticisms. Broadly, water management was } \\
\text { based on flood control and drainage and } \\
\text { irrigation management, and decision } \\
\text { making was BWDB-centric. }\end{array}$ & $\begin{array}{l}\text { Due to the devastating floods in } 1987 \text { and } \\
\text { 1988, flood controlling received } \\
\text { international attention and donors' } \\
\text { support. However, NGOs, civil societies } \\
\text { criticised FAP, since it discouraged } \\
\text { decentralized decision making. Minor } \\
\text { irrigation (e.g., shallow tube wells) was } \\
\text { flourished in this time owing to } \\
\text { privatization of irrigation technology } \\
\text { business and substantial reduction of } \\
\text { government taxes. }\end{array}$ & $\begin{array}{l}\text { Water management was based on flood } \\
\text { control and drainage, albeit water crisis in } \\
\text { the dry season and droughts were becoming } \\
\text { an increasing concern. Enacting Upazila } \\
\text { (Sub-district) Parishad Act 1998, formulating } \\
\text { LGED guidelines on how to involve local } \\
\text { people in water projects, strengthening local } \\
\text { government institutions and provisioning } \\
\text { impact assessment and applying EIA } \\
\text { practice in approving projects were main } \\
\text { issues of this era. }\end{array}$ & $\begin{array}{l}\text { Several strategic initiatives were taken such as } \\
\text { facilitating partnerships and devolutions of } \\
\text { power. The government had approved a } 25 \text { years } \\
\text { NWMP and developed other instruments, } \\
\text { namely BWDB Strategic Plan 2009-2014, } \\
\text { National Water Act 2013, and Haor (flooded } \\
\text { tectonic depressions) Master Plan 2012-2032. } \\
\text { However, the challenges lie in implementation of } \\
\text { these instruments as the country has shortage of } \\
\text { resources and political will. }\end{array}$ \\
\hline
\end{tabular}


Alternatively, the National Sustainable Development Strategy addresses the seasonal fluctuations of crisis between flood and drought in Bangladesh [49] by providing for improved community access to decision making, the incorporation of indigenous knowledge, and a policy direction toward sustainable water management. However, the Strategy does not provide guidelines for how the major consumers of water such as agriculture and energy producers can be integrated and coordinated to enhance co-benefits of water sustainable water management [16,49].

The National Adaptation Plan 2005 was created in response to five challenges of climate change facing Bangladesh: scarcity of fresh water; drainage congestion; river bank erosion; frequent floods; and widespread drought and wider salinity [43]. Water is at the heart of climate change adaptation, however, the Plan does not put emphasis on water management-based adaptation measures except "land-water zoning" [43,50]. This is not surprising, as adaptation measures based on water resources management generally, or IWRM specifically, are often underrepresented in national plans and in international investment portfolios [51]. Likewise, IWRM is not treated as an important tool in other climate change adaptation policies such as the Bangladesh Climate Change Strategy and Action Plan 2009 [52]. Incorporating the structured approach of IWRM to climate change adaptation policies in Bangladesh could be useful in promoting water policy integration both vertically (policies that achieve multiple goals across sectors) and horizontally (policies that support consolidation of resources and effort) and thus could serve to coordinate fragmented institutional capacity and organizational resources aimed at sustainable water development [13].

\subsection{Existing Water Policies}

Table 1 describes four eras of water policy evolution in Bangladesh from the 1950s to present and illustrates that relatively few policy instruments have been created to address water governance. In addition, several existing policies are out-of-date in terms of addressing rapid environmental change, and although Bangladeshi water policies are partly integrated with environmental issues such as agriculture and sanitation, issues of climate change are utterly ignored (see Table 2). Environmental and climate policy integration is essential for IWRM planning and implementing [9], to effectively address the water-energy-food nexus [19] and to advance toward sustainable development [53].

Recently, the government promulgated the Water Act 2013, envisaging integrated surface-groundwater development and more robust systems of water distribution and protection [45]. The act does not indicate how the government will address related issues such as land grabbing, river encroachment, and the establishment of treatment plants for industrial effluent. A major drawback of this policy is that no court can accept a lawsuit aimed at enforcing the provisions of this act without a written complaint from the Director General of the Water Resource Planning Organisation or his/her appointee. The Act undermines the power of citizens and NGOs by stating that no individual or organization will be allowed to file a law suit against other individuals, organizations, or government authority for violating the provisions of the Act [45]. In contrast, the Act gives absolute power to the Executive Committee under the Ministry of Water Resources for taking actions that they deem necessary to implement provisions of the act.

Although the Government of Bangladesh has created policies to address water governance issues (see Tables 1 and 2), very little attention is paid to how these policies are implemented at the local level [42]. Mandal [54] observes that most policies are prepared on the basis of national ideals that lack empirical assessment and a vision for implementation at scale. The lack of any real implementation or evaluation of outcomes is a considerable burden to promoting sustainable development [53] and to holistic improvements in water governance. 
Table 2. Environmental and climate policy integration of major national policies of WRM.

\begin{tabular}{|c|c|c|c|c|c|}
\hline Policy Instrument & Inclusion & Consistency & Weighting & Reporting & Resources \\
\hline \multicolumn{6}{|c|}{ Environmental Policy Integration (EPI) } \\
\hline National Water Policy [31] & $\begin{array}{l}\text { Explicitly discusses as "water for } \\
\text { the environment". }\end{array}$ & $\begin{array}{l}\text { "Protection of the environment" } \\
\text { states a fair consistency. }\end{array}$ & $\begin{array}{l}\text { Importantly presented, signifying an } \\
\text { efficient and equitable water use. }\end{array}$ & $\begin{array}{l}\text { Reporting and evaluation systems } \\
\text { are weaker. Poor } \\
\text { monitoring systems. }\end{array}$ & $\begin{array}{l}\text { Lacking of resources, e.g., financial } \\
\text { and technological. }\end{array}$ \\
\hline $\begin{array}{c}\text { Development Strategy of the } \\
\text { National Water Management } \\
\text { Plan [32] }\end{array}$ & $\begin{array}{l}\text { Carefully includes measures for } \\
\text { environment protection } \\
\text { and improvement. }\end{array}$ & $\begin{array}{l}\text { Indirectly, as it creates avenues } \\
\text { for efficient management }\end{array}$ & $\begin{array}{l}\text { "Health and environment strategy" } \\
\text { is a major strategic choice of } \\
\text { this document. }\end{array}$ & $\begin{array}{l}\text { Weaker reporting provision. Suggests } \\
\text { applying evaluation tools, e.g., EIA. }\end{array}$ & $\begin{array}{l}\text { States challenges. GOs, IOs and DOs } \\
\text { provide supports. }\end{array}$ \\
\hline $\begin{array}{c}\text { National Water Management } \\
\text { Plan [21] }\end{array}$ & $\begin{array}{l}\text { "Protection of the natural } \\
\text { environment" states as a major goal. }\end{array}$ & $\begin{array}{l}\text { Partly. Economic development is } \\
\text { a prime issue. }\end{array}$ & $\begin{array}{l}\text { Considerably significant as water } \\
\text { pollution is a pressing issue. }\end{array}$ & $\begin{array}{l}\text { Includes a detailed plan for } \\
\text { coordination, monitoring } \\
\text { and reporting. }\end{array}$ & $\begin{array}{l}\text { States a brief funding plan } \\
\text { (donor-dependent), } \\
\text { indicating challenges. }\end{array}$ \\
\hline \multicolumn{6}{|c|}{ Climate Policy Integration (CPI) } \\
\hline National Water Policy 1999 & Not Included. & Inconsistent. & $\begin{array}{l}\text { The Term "Climate Change" is } \\
\text { Not Used. }\end{array}$ & No & No \\
\hline $\begin{array}{l}\text { Water sector Development } \\
\text { Strategy } 2001\end{array}$ & $\begin{array}{l}\text { Climate change issue } \\
\text { inadequately includes. }\end{array}$ & Broadly consistent. & $\begin{array}{l}\text { States only the sea level rise concern } \\
\text { and reports more researches are } \\
\text { needed on it. }\end{array}$ & $\begin{array}{l}\text { Weaker reporting systems due to } \\
\text { financial and technical limitations. }\end{array}$ & $\begin{array}{l}\text { No. However, it reports caveats such } \\
\text { as flood, arsenic contamination, and } \\
\text { natural calamities. }\end{array}$ \\
\hline $\begin{array}{l}\text { National Water Management } \\
\text { Plan } 2004\end{array}$ & Inexplicitly. & $\begin{array}{l}\text { Inconsistent. It only states in the } \\
\text { baseline of the plan. }\end{array}$ & $\begin{array}{l}\text { Climate change problems } \\
\text { insignificantly presented. }\end{array}$ & $\begin{array}{l}\text { Knowledge gaps on climate change } \\
\text { impacts are acknowledged. }\end{array}$ & No \\
\hline
\end{tabular}

Notes: A. Inclusion: to what extent are policy documents directly and indirectly covered environmental/climate change (Env/CmC) policy objectives? Consistency: have the contradictions between the aims of relating to Env/ $\mathrm{CmC}$ and other policy goals been assessed and have there been efforts to minimize revealed contradictions? Weighting: has the relative priority of Env/CmC compared to other policy aims been decided and are there procedures for determining the relative priorities? Reporting: Are there clearly stated evaluation and reporting requirements for Env/ $\mathrm{CmC}$ ex-ante and have such evaluations for reporting happened ex-post? Resources: has financial and human resources use for the implementation of Env/CmC objectives and impact assessment been specified? B. A detailed explanation on policy integration evaluation is found in Kivimaa \& Mickwitz [55], and Roy \& Chan [53]. 


\subsection{Politics and Decision Making}

Bangladesh has strong elements of democracy, e.g., freedom of the press and media. However, there is a recognized lack of transparency and accountability in environmental decision-making processes in Bangladesh [18]. The current political system is essentially a "winner take all" system due to the outright exclusion of political opposition from a legitimate place in the democratic polity, the undue influence of state institutions to achieve political interests, and the general politicization of bureaucracy [16]. Bureaucratic complexities common to many forms of democratic governance affect administrative functions in Bangladesh, and with very few enforceable checks and balances in government, give rise to petty corruption and crime across the water management administration [56]. Although corruption of public officials is a state-wide issue, it has implicit and explicit associations with institutions and/or organizations that manage water resources [34]. For example, protracted or corrupt bureaucratic procedures and a lack of transparency in most public services offices is a major barrier to implementing the Rights to Information Act of 2009 [57] - the application of which is very important measure for obtaining water management data from the Ministry of Water Resources to support IWRM and improved water decision making [16].

Unlike other South Asian countries, Bangladesh has managed to maintain its political stability, despite a recent internal transition in party governance and subsequent evidence of an erosion of democratic decision-making processes. The ruling party (Bangladesh Awami League) in the national government has increasingly excluded any opposition parties from major decision making forums. This in turn has led to a stagnation of many government functions. For example, many parliamentary committees such as the Standing Committee of the Ministry of Water Resources have not yet been formed.

Decision making in Bangladesh is highly centralized; long-term and systematic stakeholders' engagement for transparent decision making and effective water management is hardly practiced [58]. Water resource management in Bangladesh is fragmented and public participation in water projects is sparse if encouraged at all $[17,28]$. The lack of focus on IWRM and effective water governance can be traced to a constant struggle to address basic challenges for achieving water related MDG goals such as extremely poor quality of public water services and inefficient systems for operations and maintenance of existing infrastructure [58]. These shortcomings are compounded by regional socioeconomic disparities, inequity in access and weak institutional scaffoldings [18,59].

Beyond the state borders, the status of transboundary rivers area significant water governance concern in Bangladesh [22]. The productivity of Bangladeshi agriculture rests on its geographic position as a delta for major Asian rivers draining the Himalayan Mountain range and the abundant, seasonal supply of surface water resources. Historically, the present government and political party have attempted resolve transboundary river conflicts with the adjacent and upstream hegemon, India. While no notable results have been achieved, the Bangladeshi government recently formed a National River Commission to oversee the whole issue of transboundary river management. According to the Commission's organic law, however, the Commission can only provide "recommendations" to the government. In the context of the contemporary political climate in Bangladesh, this Commission is essentially what many refer to as a "toothless tiger" and thus transboundary issues will likely remain a concern for water governance and the prospect of implementing IWRM.

\section{Materials and Methods}

In the previous section, we reviewed the institutional and political contexts of water governance in Bangladesh. This background serves as a basis from which we deductively determine initial strengths, weaknesses, opportunities and threats (SWOT) for a hybrid quantitative analysis of major water organizations and institutions in Bangladesh. Below, we detail this process including the refinement of SWOT factors based on 44 informal interviews with policy makers, researchers, consumers, and NGO workers, each with more than one decade of related professional experience working with water resources issues in Bangladesh and/or related international settings. We employed a semi-structured 
questionnaire to guide interviews, and included questions designed to uncover the institutional and political opportunities, constraints and barriers to effective water governance in Bangladesh. The determination of the final SWOT factors used in the quantitative analysis were thus informed both deductively from peer-reviewed literature and policy documents as well as inductively from interview data, and thus triangulated for increased robustness of results [60]. The second author collected and analyzed data from July 2013 to March 2014.

SWOT is a method of conducting a situation analysis of internal (strengths and weaknesses) and external (opportunities and threats) factors, which influence decision making [61]. SWOT factor identification can inform resource planning to achieve predetermined objectives, e.g., strengthening water governance. However, the meaningfulness of identified SWOT factors cannot be quantified by employing the conventional SWOT analysis alone [61]. The application of an analytical hierarchy process (AHP) is useful to overcome this shortcoming by assigning relative priority to each factor through a process of pair wise comparisons [62]. To determine the identified SWOT factors of most influence to strengthening water governance in Bangladesh, AHP was combined with SWOT analysis via the following steps: (i) identification of all potential SWOT factors from a literature review and semi-structured interviews; (ii) pair-wise comparison of factors within each SWOT group; and (iii) pair-wise comparison across the four SWOT groups. This hybrid method is discussed and tested by Kurtilla, Pesonen, Kangas, and Kajanus [63] and Masozera et al. [61].

Of the 44 experts interviewed in an effort to determine factors for the SWOT analysis, 26 interviewees were additionally asked to complete pair wise comparison questions of SWOT factors (see Figure 1 for an example question). In the pair wise comparisons (see Equation (A1) in Appendix A) of factors within each SWOT group, the factor with the highest priority value was brought forward for further comparisons. These leading factors among the four SWOT groups-strengths, weaknesses, opportunities and threats-were then compared as in a similar pair wise process by the first author. After completing all pair-wise comparisons, priority values of the groups, priority values of the factors within the groups and consistency ratios were computed using the Eigen value method (see Saaty and Vargas [62] and Equation (A2) in Appendix A). The consistency ratios (Equation (A3) in Appendix A) were kept below or equal to $10 \%$ to remain the inconsistencies within an acceptable level. If the consistency ratio is greater than $10 \%$, a revision of the subjective judgment was required.

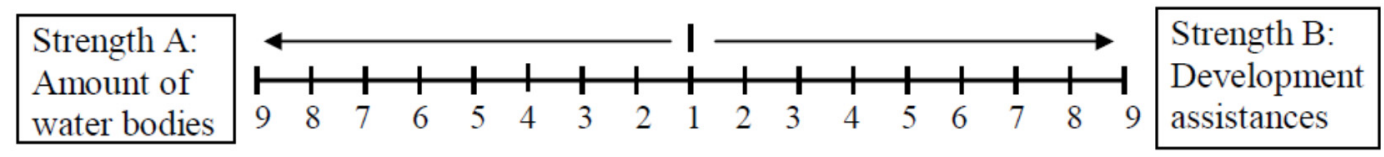

Figure 1. A sample questionnaire of a pair wise comparison between strength factors. Respondents were requested to compare the importance of the two factors and based on his preferences of the particular factor he was asked to assign a weight from 1 to 9 for the relatively important factor to reflect the magnitude of the importance. The same process was followed for all pair wise comparisons.

\section{Findings and Discussion}

\section{A SWOT-AHP Analysis of Water Institutions}

We employed a SWOT-AHP analysis of water governance institutions and organizations in Bangladesh to derive decisive information on specific "factors" influencing the strengths, weaknesses, opportunities, and threats facing these institutions and organizations and to shed light on the potential to implement IWRM approaches in Bangladesh. We kept the number of factors within each SWOT group to below 10 purposely to ensure the number of pair wise comparisons is manageable [61]. Table 3 presents the factors, their priority scores, and the overall priority scores, which provide valuable insights for discussion. The priority score of a specific factor within a SWOT group can be interpreted as its relative contribution of that factor to the respective category. The priority scores of the factor within each category sum up to 1 , which indicates that the overall score of a factor 
can be interpreted as the percentage of each factor's contribution relative to the broader category (e.g., strength, weakness, opportunity, or threat). For example, the overall priority score of the factor "amount of water bodies" under the "strength" category is 0.14 , which generally indicates that $14 \%$ of water experts surveyed perceive that numerous water bodies such as rivers and lakes are an important strength for mitigating water crises in Bangladesh.

Table 3. Priority and consistency ratio ${ }^{\mathrm{a}}$ of the SWOT factors and groups, including the overall priority of the factors.

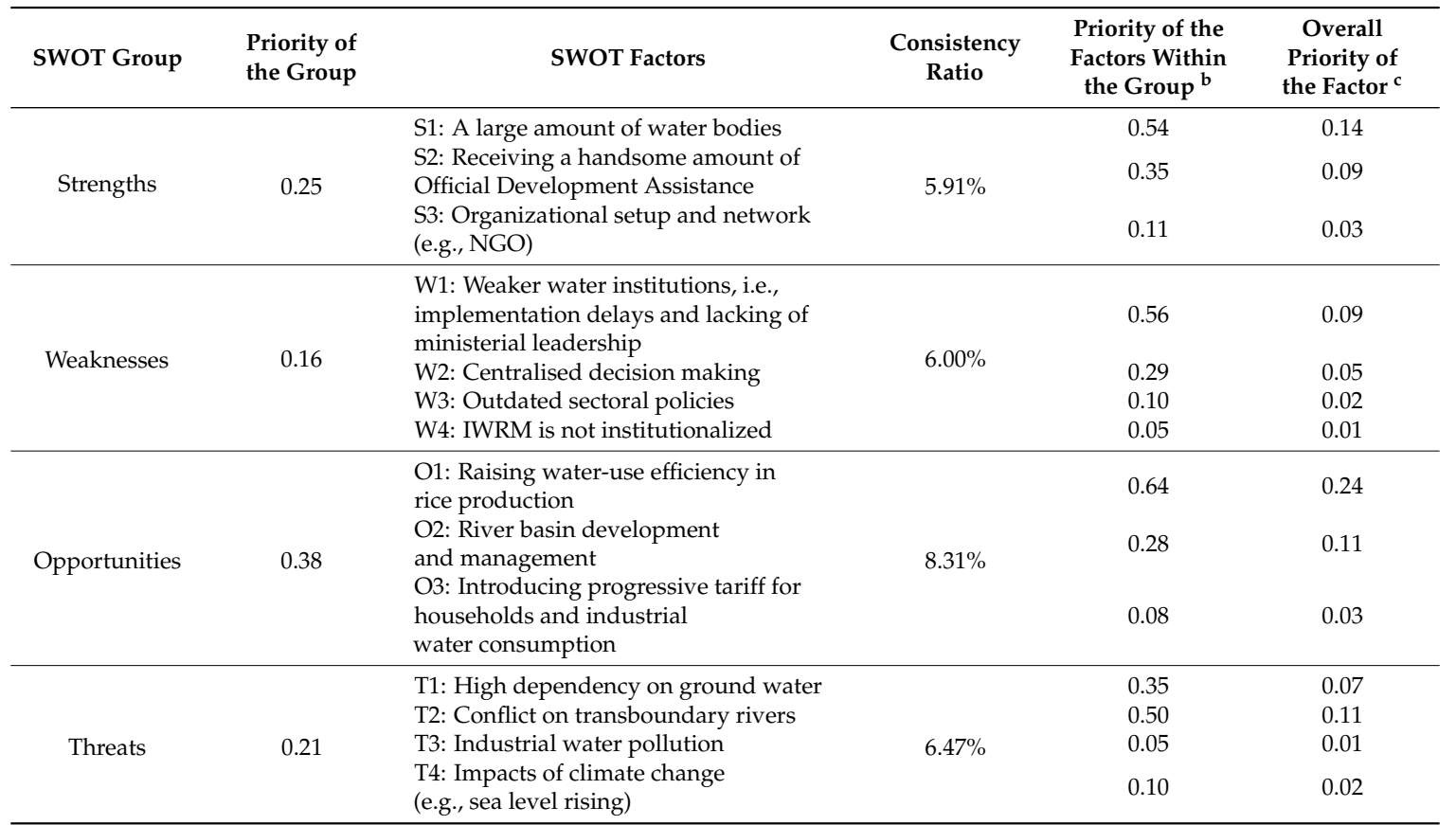

Notes: a The consistency ratio (Equation (A3), see Appendix A) of the comparisons between four SWOT groups was $8.28 \%$; b Factor priority score is the normalized Eigen vector of a comparison matrix; ${ }^{\mathrm{c}}$ The overall priorities of the factors were calculated by multiplying the priority of the factor within the group by the priority of the group.

Results from the SWOT-AHP analysis quantitatively indicate the importance of six SWOT factors: two strengths, one weakness, two opportunities, and one threat (Table 3). Quantitatively the biggest overall priority assigned to SWOT factors indicates the most explanatory power relative among factors. Here, we have placed emphasis on quantitatively important SWOT factors for interpretation and discussion of how these factors might influence the implementation of an IWRM approach.

The SWOT-AHP analysis identified key opportunities to pursue increased integration and sustainability in water policy and management in Bangladesh, most notably "Raising water-use efficiency" in rice production (Table 3). Previous literature explicitly indicates that irrigation water is used inefficiently in Bangladesh rice farming [14,15]. On average, only $25 \%-30 \%$ of irrigation water is used by crops and the rest is lost due to inefficient flood irrigation systems [46]. From time immemorial, Bangladeshi growers have cultivated rice using traditional practices of flooding fields [64]. These practices lead to a huge amount of water loss through percolation, seepage and surface runoff as well as increased transpiration and evaporation. The opportunity to increase water use efficiency in Bangladesh rice farming may include adopting more appropriate agronomic practices such as the alternative wetting and drying method; breeding suitable rice varieties that consume less water; or revamping agricultural extension systems towards local innovations, e.g., fuel-efficient pumps. Additionally, it is equally important for Bangladeshi producers to develop integration schemas for conjunctive management of surface and ground water and to pursue economic incentives such as price supports aimed at diversifying crop production towards crops that require much less water. 
The Bangladesh landscape is gifted with many rivers and rivulets and this was recognized in the SWOT-AHP analysis by "a large amount of water bodies" emerging as an important strength. However, mismanagement of river resources (e.g., haphazard infrastructure development) has increased the damaging effects of seasonal flooding, exacerbating already wide spread pollution problems. Consequently, Bangladesh has turned to groundwater as a major source for irrigation, drinking and industry. The SWOT analysis also identified "river basin development and management" as a good opportunity to alleviate the threat of high dependency on groundwater (and the consequent arsenic contamination of groundwater). This finding is concurs with the findings of Rahaman [22] and Asaduzzaman et al. [15], who stated that river basin development is a potential area of the government investment to rejuvenate the river flow and focal point from which to develop an achievable IWRM plan. Thus, capacity building of governmental organizations such as the Bangladesh Water Development Board and local community governments is essential in coordinating development of surface waters including improved flood control infrastructure. However, these opportunities do not address water supply and distribution issues, nor do they indicate existing capacity for an IWRM approach such as, public investment for long-term planning or the emergence of transparent and accountable decision making based on sound science and data sharing.

Bangladesh's official development assistance represents a significant potential strength that can be leveraged to achieve IWRM. From 2007 to 2011, Bangladesh received development assistance equivalent to USD 177.69 million on average per year for water infrastructure development. During the same period, the government invested USD 259.30 million on average per year for the same purposes [65]. Nonetheless, weak water institutions and centralized but ineffective decision making related to water infrastructure and regulation has hamstrung any progress toward implementing IWRM $[17,58,66]$. While Bangladesh has made some progresses in formulating policy instruments and strategies [14], an appropriate planning initiative and strategy are needed to fully institutionalize IWRM across water management at all levels in Bangladesh [30]. Experts interviewed for this research identified development assistance as a strength of potentially emergent changes in water governance, and relayed optimism that existing institutions (and some organizations) are improving management and technical capacity at increasing scales.

Conflicts over transboundary rivers have emerged as a major threat to developing further integrated water governance in Bangladesh. This result is counter to results reported by Gain and Giupponi [23]. This finding is most likely an outcome of recent severe water shortage in the Teesta River-the fourth largest trans-national river in Bangladesh. In 2014, a water shortage in Teesta was headline news in daily national and international newspapers (e.g., The Daily Star). Without the consultation or involvement of Bangladesh, the Indian government is planning to build a number of river linking projects, namely the "Tipaimukh Dam" construction, to divert the Barak River toward other states. Second, there is widespread speculation about China's plans to build a dam at the Great Bend on Yarlung Tsangpo (Brahmaputra) and how such an impoundment would greatly reduce river flows during the low flow season. In addition, survey respondents indicated that "conflicts on transboundary rivers", "dependency on ground water" and "impacts of climate change" as an "imminent threat" to this country.

\section{Conclusions and Policy Implications}

This study attempts to develop a conceptual space for expanding IWRM in Bangladesh by analyzing the current institutional and political contexts of water governance in the country. The governance system (ministerial) for policy development in Bangladesh (see [19] for a detailed description of the process) is not currently conducive to foster policy integration between water, environment, and climate change policy necessary for the successful implementation of IWRM. Our findings further indicate that there is currently no adequate policy framework in place for the coordination of existing governance or for the sharing of co-benefits of water resources in Bangladesh. We find that this lack of coordination further exacerbates fragmentation among existing organizations 
and institutions charged with developing and implementing water management policies. At the same time, however, fragmentation between existing governance structures presents an opportunity for an IWRM approach. Governance coordination can be improved by forging a governance arrangement that offers an appropriate mix of local and regional institutions, with strong support for strengthening of these local institutions by national authorities. To establish coordination in governance, it is essential to focus on: consolidating water institutions' duties and responsibilities; clarifying governance and management roles; and developing mechanisms to coordinate across water-related sectors such as agriculture, energy and environment (e.g., climate change). Sharing co-benefits is a practical policy tool to reduce conflicts as well as to achieve greater social inclusiveness and balance economic, environmental, and social factors in planning, design and implementation of water resource management. However, political will and democratic accountability are essential for stable and reliable governance coordination, and this represents a significant hurdle for Bangladesh.

The analysis of strengths, weaknesses, opportunities, and threats presented in this paper highlight critical factors that represent both barriers and bridges to the potential future implementation of an IWRM approach in Bangladesh. Bangladesh is endowed with substantial water resources and despite significant and increasing water quality concerns and scarcity concerns, water resources in Bangladesh are viewed as an asset. This factor alone should represent political and social capital for increasing attention to water resource policy, including potential integration of water into other policy arenas. The substantial development assistance received by Bangladesh can and should be leveraged toward water development that coincides with other important goals of public policy including food and energy security and concerns over environmental quality and the impacts of climate change. One significant opportunity discussed herein lies in raising water use efficiency among agricultural producers (mainly in rice cultivation). Our research identified conflict (and potential conflict) on transboundary rivers as the most significant threat facing water governance in Bangladesh as unilateral upstream developments by India, China, Nepal, and Bhutan threaten the availability of water during the already water-scare dry seasons (November-May) in Bangladesh. However, we also identified river basin development as an important opportunity for pursing an IWRM approach in the region. While it is difficult to imagine a sudden shift in diplomatic relations between Bangladesh and India in the near future, the vulnerability of Bangladesh to the effects of climate change may provide some substantial grounding for international diplomacy that encourages integrated development of the Ganges-Brahmaputra River Basin and the implementation of an IWRM approach (perhaps facilitated or mediated by a non-riparian body) at a regional and hydrologically relevant scale that is multinational in scope.

Within Bangladesh, a number of water and other related policy instruments are out-of-date due to the lack of integration of climate change considerations. Incorporating climate change policy into surface-groundwater water planning is crucial to achieving sustainable management of water resources - as well as a sustainable implementation of IWRM. Anecdotal evidence suggests that if policy integration is assigned increased political importance, is subjected to increased institutional coordination and harmonization, and receives increased ministerial support and resources, it would have greater leverage.

Our assessment of the institutional and political contexts of water governance in Bangladesh leads us to suggest distinct policy strategies to foster space for the development of IWRM, and to support the SDGs for water in Bangladesh. First, a significant opportunity exists to unite water governance in Bangladesh around policies supporting increased (farm) water use efficiency. Our SWOT-AHP shows salience around this opportunity that could serve to unite water experts and the general public (farmers, communities) through information sharing, diffusion of new technology and shared governance, as well as the aid and development community for coordinated funding and support. This opportunity to foster contexts of IWRM could improve individual growers' water harvesting abilities, build capacity for local water organizations and spread technical innovations such as rotational irrigation and drought resistant crop varieties. Second, significant government and NGO investments 
must be made and coordinated toward building more transparent, inclusive and accountable water governance institutions at the state, regional and local scales. These institutions would benefit from increased data sharing, not only of hydrologic data, but also relevant economic, environmental and social data as well as information on cultural norms affecting all related water-using sectors. Moreover, public and private active participation in water management decision making is essential - both the capacity and the incentive for public participation must be fostered. Third, to reduce impacts from water-related disasters and to improve general access to water surface water, a transboundary rivers' treaty (or transboundary river policy or organization) should be pursued amongst upstream riparians (most notably India as the basin hegemon) incorporating the international principles of equitable utilization of shared resources, transparent information exchange and cooperation. To accomplish these policy recommendations, a close coordination between the Bangladesh Water Development Board and local governance actors (whether that be community leaders or development organizations working across the country) is essential to develop long-term planning mechanisms, establish new lower-cost irrigation schemes, and to link varied channels of investment to promote effective water governance through the development of IWRM.

Acknowledgments: The authors acknowledge the funding in the research grant titled "Effects of Floods on Human Society and the Role of Social Capital in Recovery in Malaysia", Fundamental Research Grant (FRGS) from Ministry of Education Malaysia, Account Number 203/PHUMANITI/6711393 which funded the research, produced the data and finally the publication of this paper.

Author Contributions: Ranjan Roy and Chan Ngai Weng contributed to the conception and design of the study. Ranjan Roy led the collection and analysis of data and drafting the manuscript. Brian C. Chaffin interpreted the results, edited and reviewed the article.

Conflicts of Interest: The authors declare no conflict of interest.

\section{Appendix A}

\section{A pair-wise comparison of a matrix (A):}

$$
\mathrm{A}=\left(\alpha_{\mathrm{ij}}\right)=\left[\begin{array}{cccc}
1 & \mathrm{w}_{1} / \mathrm{w}_{2} & \cdots & \mathrm{w}_{1} / \mathrm{w}_{\mathrm{n}} \\
\mathrm{w}_{2} / \mathrm{w}_{1} & 1 & \cdots & \mathrm{w}_{2} / \mathrm{w}_{\mathrm{n}} \\
\vdots & \vdots & \cdots & \vdots \\
\mathrm{w}_{\mathrm{n}} / \mathrm{w}_{1} & \mathrm{w}_{\mathrm{n}} / \mathrm{w}_{2} & \cdots & 1
\end{array}\right]
$$

Information derived from pair-wise comparisons can be presented as a reciprocal matrix of weights $(w)$, where the assigned relative weight enters into the matrix as an element $\alpha_{i j}$ and reciprocal of the entry $1 / \alpha_{i j}$ goes to the opposite side of the main diagonal. In the matrix, when $i=j, \alpha_{i j}=1$.

In pair wise comparisons, some inconsistencies can be expected and accepted. When " $\mathrm{A}$ " contains inconsistencies, the estimated priorities can be obtained by using the matrix (Equation (A1)) as the input using the Eigen value technique (Equation (A2)).

$$
(A-\lambda \max \cdot \mathrm{I}) \mathrm{q}=0
$$

Here, $\lambda \max$ is the principal Eigen value of matrix A, " $\mathrm{I}$ " is the identity matrix and " $\mathrm{q}$ " is the correct Eigen factor. The " $q$ " constitutes the estimates of relative priorities. It is the first principal component of the matrix of pair wise comparisons. Again, " $q$ " is the exact estimate of the priority vector, when the matrix does not include any inconsistencies. Each Eigen factor is scaled to sum up to one to obtain the priorities. More information on the Eigen value technique can be found elsewhere [67].

\section{Calculating the consistency ratio}

$$
\text { Consistency Ratio }(\mathrm{CR})=\text { Consistency Index (CI)/Random Consistency Index (RI) }
$$


$C I=(\lambda \max -n) /(n-1)$. Here, $\lambda \max$ means the principal Eigen value, which is obtained from the summation of products between each element of Eigen vector and the sum of columns of the reciprocal matrix. " $n$ " is the size comparison matrix $=3$ (see Equation (A1)). RI for $n=3$ is 0.58 [66].

\section{References}

1. Bates, B.C.; Kundzewicz, Z.W.; Wu, S.; Palutikof, J.P. Climate Change and Water: IPCC Technical Paper VI; Cambridge University Press: Cambridge, UK, 2008.

2. United Nations Intergovernmental Panel on Climate Change (IPCC). Climate Change 2014: Impact Adaptation and Vulnerability. Summary for Policymakers. Contribution of Working Group II to the 5th Assessment Report of the IPCC; Cambridge University Press: Cambridge, UK, 2014.

3. World Water Assessment Programme (WWAP). The United Nations World Water Development Report 4: Managing Water Under Uncertainty and Risk; United Nations Educational, Scientific and Cultural Organization: Paris, France, 2012.

4. Rogers, P.; Hall, A.W. Effective Water Governance, TEC Background Papers No. 7, Global Water Partnership Technical Committee (TEC) Background Papers; Global Water Partnership: Stockholm, Sweden, 2003.

5. Pahl-Wostl, C.; Gupta, J.; Petry, D. Governance and the global water system: A theoretical exploration. Global Govern. A Rev. Multilateralism Int. Org. 2008, 14, 419-435.

6. Huitema, D.; Mostert, E.; Egas, W.; Moellenkamp, S.; Pahl-Wostl, C.; Yalcin, R. Adaptive water governance: Assessing the institutional prescriptions of adaptive (co-) management from a governance perspective and defining a research agenda. Ecol. Soc. 2009, 14, 26. Available online: http:/ /www.ecologyandsociety.org/ vol14/iss1/art26/ (accessed on 13 September 2016).

7. Cosens, B.; Gunderson, L.; Chaffin, B. The Adaptive Water Governance Project: Assessing Law, Resilience and Governance in Regional Socio-Ecological Water Systems Facing a Changing Climate. Nat. Resour. Environ. Law Ed. Idaho Law Rev. 2014, 51, 1-27.

8. Green, O.O.; Garmestani, A.S.; Allen, C.R.; Ruhl, J.B.; Arnold, C.A.; Gunderson, L.H.; Graham, N.A.J.; Cosens, B.; Angeler, D.G.; Chaffin, B.C.; et al. Barriers and Bridges to the Integration of Social-Ecological Resilience and Law. Fronti. Ecol. Environ. 2015, 13, 332-337. [CrossRef]

9. Reichert, P.; Langhans, S.D.; Lienert, J.; Schuwirth, N. The conceptual foundation of environmental decision support. J. Environ. Manag. 2015, 154, 316-332. [CrossRef] [PubMed]

10. United Nations (UN). Transforming Our World: The 2030 Agenda for Sustainable Development; United Nations: New York, NY, USA, 2015.

11. Global Water Partnership (GWP). Integrated Water Resources Management; TAC Background Paper No 4; Global Water Partnership: Stockholm, Sweden, 2000.

12. Gain, A.K.; Rouillard, J.J.; Benson, D. Can Integrated Water Resources Management increase adaptive capacity to climate change adaptation? A critical review. J. Water Resour. Protect. 2013, 5, 11-20. [CrossRef]

13. Rouillard, J.J.; Heal, K.V.; Ball, T.; Reeves, A.D. Policy integration for adaptive water governance: Learning from Scotland's experience. Environ. Sci. Policy 2013, 33, 378-387. [CrossRef]

14. Chowdhury, N.T. Water management in Bangladesh: an analytical review. Water Policy 2010, 12, 32-51. [CrossRef]

15. Asaduzzaman, M.; Ringler, C.; Thurlow, J.; Alam, S. Investing in Crop Agriculture in Bangladesh for Higher Growth and Productivity, and Adaptation to Climate Change. In Proceedings of Bangladesh Food Security Investment Forum, Dhaka, Bangladesh, 26-26 May 2010.

16. World Bank. Bangladesh-Country Water Resources Assistance Strategy; Report No. 32312-BD; Environment and Social Development Unit: Washington, DC, USA, 2005.

17. Gupta, A.D.; Babel, M.S.; Albert, X.; Mark, O. Water sector of Bangladesh in the context of integrated water resources management: A review. Water Resour Dev. 2005, 21, 385-398. [CrossRef]

18. Rouillard, J.J.; Benson, D.; Gain, A.K. Evaluating IWRM implementation success: Are water policies in Bangladesh enhancing adaptive capacity to climate change impacts? Int. J. Water Resour. Dev. 2014, 30, 515-527. [CrossRef]

19. Gain, A.K.; Giupponi, C.; Benson, D. The water-energy-food (WEF) security nexus: The policy perspective of Bangladesh. Water Int. 2015, 40, 895-910. [CrossRef] 
20. Ahmed, A.U.; Huq, S.; Nasreen, M.; Hassan, A.W.R. Climate Change and Disaster Management, Sectoral Inputs towards the Formulation of the 7th Five Year Plan (2016-2021); Bangladesh Planning Commission: Dhaka, Bangladesh, 2015; p. 63.

21. Water Resources Planning Organisation (WaRPO). National Water Management Plan 2001; Government of Bangladesh; Ministry of Water Resources: Dhaka, Bangladesh, 2004.

22. Rahaman, M.M. Integrated Ganges Basin Management: conflicts and hope for regional development. Water Policy 2009, 1, 168-190. [CrossRef]

23. Gain, A.K.; Giupponi, C. Impact of the Farakka Dam on thresholds of hydrologic flow regime in the Lower Ganges River Basin (Bangladesh). Water 2014, 6, 2501-2518. [CrossRef]

24. Kolås, A.; Edelen, K.; Jahan, F.; Barkved, L.; Hoelscher, K.; Jha, H.B.; Bhattacharjee, J.; Holen, S.; Miklian, J. Water Scarcity in Bangladesh: Transboundary Rivers, Conflict and Cooperation; PRIO Report 1-2013; Peace Research Institute Oslo (PRIO): Oslo, Norway, 2013.

25. Gain, A.K.; Giupponi, C. A dynamic assessment of water scarcity risk in the Lower Brahmaputra River Basin: An integrated approach. Ecol. Indic. 2015, 48, 120-131. [CrossRef]

26. Global Water Partnership-South Asia (GWP-SAS). National Stakeholder Consultations on Water: Supporting the Post-2015 Development Agenda. Available online: http://www.gwp.org/Global/GWP-SAs_Files/ News\%20and\%20activities/Bangladesh\%20Final\%20National\%20Consultation\%20Report.pdf (accessed on 30 December 2015).

27. Benson, D.; Gain, A.K.; Rouillard, J.J. Water governance in a comparative perspective: from IWRM to a 'nexus' approach? Water Alternatives 2015, 8, 756-773.

28. Dewan, C.; Mukherji, A.; Buisson, M.C. Evolution of water management in coastal Bangladesh: From temporary earthen embankments to depoliticized community-managed polders. Water Int. 2015, 40, 401-416. [CrossRef]

29. Gain, A.K.; Schwab, M. An assessment of water governance trends: the case of Bangladesh. Water Policy 2012, 14, 821-840. [CrossRef]

30. United Nations Environment Program (UNEP). Status Report on the Application of Integrated Approaches to Water Resources Management; UN-Water Reports; UNEP: Nairobi, Kenya, 2012.

31. Ministry of Water Resources (MoWR). National Water Policy; Government of Bangladesh; Ministry of Water Resources: Dhaka, Bangladesh, 1999.

32. Water Resources Planning Organisation (WaRPO). Development Strategy of National Water Management Plan; Government of Bangladesh; Ministry of Water Resources: Dhaka, Bangladesh, 2001.

33. United Nations Development Program (UNDP). Water Governance for Poverty Reduction. Key Issues and the UNDP Response to the Millennium Development Goals; UNDP: New York, NY, USA, 2004.

34. Gupta, J. An essay on global water governance and research challenges. In Principles of Good Governance at Different Water Governance Levels, Proceedings of a Workshop, Delft, The Netherlands, 22 March 2011; van der Valk, M.R., Keenan, P., Eds.; International Hydrological Programme (IHP) of the United Nations Educational, Scientific and Cultural Organization (UNESCO): Paris, France, 2011; pp. 5-12.

35. Tropp, H. Water governance: Trends and needs for new capacity development. Water Policy 2007, 9, 19-30. [CrossRef]

36. Biswas, A.K.; Tortajada, C. Future Water Governance: Problems and Perspectives. Water Resour. Dev. 2009, 26, 129-139. [CrossRef]

37. UN-Water. A Post-2015 Global Goal for Water: Synthesis of Key Findings and Recommendations from UN-Water; UN-Water: Geneva, Switzerland, 2014.

38. WHO \& UNICEF Joint Monitoring Programme (JMP). Progress on Drinking Water and Sanitation-2015 Update and MDG Assessment; World Health Organization: Geneva, Switzerland, 2015.

39. UN System Task Team. Realizing the Future We Want for All: Report to the Secretary-General; The UN System Task Team: New York, NY, USA, 2012.

40. McDonnell, R.A. Challenges for integrated water resources management: How do we provide the knowledge to support truly integrated thinking? Water Resour. Dev. 2008, 24, 131-143. [CrossRef]

41. Braga, B.P.F.; Lotufo, J.G. Integrated River Basin Plan in Practice: The São Francisco River Basin. Int. J. Water Resour. Dev. 2008, 24, 37-60. [CrossRef]

42. Pal, S.K.; Adeloye, A.J.; Babel, M.S.; Das Gupta, A. Evaluation of the effectiveness of water management policies in Bangladesh. Int. J. Water Resour. Dev. 2011, 27, 401-417. [CrossRef] 
43. Ministry of Environment and Forests (MoEF). National Adaptation Programme of Action; Government of Bangladesh; MoEF: Dhaka, Bangladesh, 2005.

44. Roy, R.; Chan, N.W.; Uemura, T.; Imura, H. The vision of agri-environmental sustainability in Bangladesh: How the policies, strategies and institutions delivered? J. Environ. Protect. 2013, 4, 40-51. [CrossRef]

45. Government of Bangladesh. Bangladesh Water Act 2013; Ministry of Water Resources: Dhaka, Bangladesh, 2013.

46. Mondal, M.H. Challenges and Opportunities of Sustainable Crop Production in Bangladesh. 8th Biennial Agronomy Convention; Bangladesh Society of Agronomy: Dhaka, Bangladesh, 2005.

47. Alam, Q.; Teicher, J. The state of governance in Bangladesh: The capture of state institutions. South Asia J. South Asian Stud. 2012, 35, 858-884.

48. International Monetary Fund (IMF). Steps towards Change National Strategy for Accelerated Poverty Reduction II; IMF: Washington, DC, USA, 2012.

49. Department of Environment. National Sustainable Development Strategy Bangladesh; Government of Bangladesh; Ministry of Environment and Forests: Dhaka, Bangladesh, 2008.

50. Cap-Net. IWRM as A Tool for Adaptation to Climate Change. A Training Manual and Facilitator's Guide. Available online: http://www.cap-net.org/wp-content/uploads/2014/05/CC-IWRM-_English-manual_ .pdf (accessed on 30 January 2016).

51. United Nations Environment Program (UNEP). Climate Change Adaptation: The Pivotal Role of Water; UN-Water Policy Brief: Nairobi, Kenya, 2011.

52. Ministry of Environment and Forests (MoEF). Bangladesh Climate Change Strategy and Action Plan 2008; Government of Bangladesh; MoEF: Dhaka, Bangladesh, 2008.

53. Roy, R.; Chan, N.W. A multi-level evaluation of policy integration of human resource development in agriculture sector. Natural Resour. 2014, 5, 119-129. [CrossRef]

54. Mandal, M.A.S. A Synthesis of Agricultural Policies in Bangladesh: Agriculture Sector Review; Ministry of Agriculture: Dhaka, Bangladesh, 2006.

55. Kivimaa, P.; Mickwitz, P. Making the Climate Count-Climate Policy Integration and Coherence in Finland; Finnish Environment Institute: Helsinki, Finland, 2009.

56. Pahl-Wostl, C. Transition towards adaptive management of water facing climate and global change. Water Resour. Manag. 2007, 21, 49-62. [CrossRef]

57. Ministry of Law, Justice and Parliamentary Affairs. Right to Information Act 2009. Available online: http://www.bbs.gov.bd/WebTestApplication/userfiles/Image/RightToInformation/RTI_ACT_ English.pdf (accessed on 30 January 2016).

58. World Bank. Country Assistance Strategy for the People's Republic of Bangladesh for the Period FY 11-14; Report No. 54615-BD; IFC, World Bank: Washington, DC, USA, 2010.

59. World Bank. Bangladesh: Country Environmental Analysis. Bangladesh Development Series Paper No. 12; World Bank: Washington, DC, USA, 2006.

60. Creswell, J.W. Qualitative Inquiry and Research Design: Choosing Among Five Approaches, 2nd ed.; SAGE Publications, Inc: Thousand Oaks, CA, USA, 2013; p. 416.

61. Masozera, M.K.; Alavalapati, J.R.R.; Jacobson, S.K.; Shrestha, R.K. Assessing the suitability of community-based management for the Nyungwe Forest Reserve, Rwanda. Forest Policy Econ. 2006, 8, 206-216. [CrossRef]

62. Saaty, T.L.; Vargas, L.G. Models, Methods, Concepts $\mathcal{E}$ Applications of the Analytic Hierarchy Process, 2nd ed.; Springer: New York, NY, USA, 2012.

63. Kurtilla, M.; Pesonen, M.; Kangas, J.; Kajanus, M. Utilizing the analytic hierarchy process (AHP) in SWOT Analysis-A hybrid method and its application to a forest certification case. Forest Policy Econ. 2000, 1, 41-52. [CrossRef]

64. Roy, R.; Chan, N.W.; Rainis, R. Rice farming sustainability assessment in Bangladesh. Sustain. Sci. 2014, 9, 31-44. [CrossRef]

65. Food and Agriculture Organization of the United Nations (FAO). AQUASTAT. Available online: http://www.fao.org/nr/aquastat/ (accessed on 10 July 2014). 
66. Roy, R.; Chan, N.W.; Xenarios, S. Sustainability of rice production systems: An empirical evaluation to improve policy. Environ. Dev. Sustain. 2016, 18, 257-278. [CrossRef]

67. Teknomo, K. Analytic hierarchy process (AHP) Tutorial. Available online: http://thecoursepm.com/Library/ AHP/AHP_Tutorial.pdf (accessed on 3 June 2014).

(c) 2016 by the authors; licensee MDPI, Basel, Switzerland. This article is an open access article distributed under the terms and conditions of the Creative Commons Attribution (CC-BY) license (http:/ / creativecommons.org/licenses/by/4.0/). 